\title{
ZNAČAJKE POST-MILENIJALACA ILI GENERACIJE Z KAO NOVIH SUDIONIKA NA TRŽIŠTU RADA
}

\author{
Prethodno priopćenje / Preliminary communication \\ UDK / UDC: $331.5: 316.346 .3$ \\ DOI: $10.51650 /$ ezrvs.15.1-2.3 \\ Primljeno / Received: 3/1/2021 \\ Prihvaćeno / Accepted: 12/2/2021
}

\begin{abstract}
Društvenim i tehnološkim razvojem mijenjaju se i značajke ljudi koji svojim međusobnim intenzivnim komuniciranjem oblikuju nove obrasce ponašanja te pogled na svijet i njegov razvoj. U posljednje vrijeme mogu se uočiti značajke ljudi rođenih od 1996. godine nadalje, a koje se naziva post-milenijalcima ili generacijom Z. Pritom se postavlja pitanje kako se ova generacija može uklopiti u zahtjeve suvremenoga poslovanja, odnosno kako njome upravljati s ciljem njihovoga doprinosa povećanju produktivnosti, efikasnosti, efektivnosti, ali i održivosti. Generaciju Z primarno određuje njihova stopljenost s informacijsko-komunikacijskom tehnologijom te konzumacija velikoga broja informacijskih sadržaja, što dovodi i do mnogih nepovoljnih značajki poput smanjenoga raspona pozornosti. Ciljovoga rada je utvrditi značajke generacije Z u svrhu definiranja smjernica upravIjanja ovih ljudima kao novim ljudskim kapitalom u smislu njihova učinkovitijega učenja, inoviranja, ali i postizanja cilja samoostvarenja.
\end{abstract}

Ključne riječi: generacija Z, post-milenijalci, upravljanje ljudskim potencijalima, učenje.

\section{Uvod}

Razni stručnjaci, menadžeri, a posebno menadžeri ljudskih potencijala intenzivno se bave razlikama u generacijama kako bi osigurali visoke razine produktivnosti, efikasnosti, efektivnosti, ali i održivosti. Tako se u posljednje vrijeme mogu uočiti specifične značajke post-milenijalaca ili generacije $Z$ kao ljudi rođenih od 1996. godine nadalje². To su, dakle, ljudi koji su dosegli dob mlađih odraslih osoba te na tržištu rada predstavljaju novu radnu snagu. Naziva ih se još i iGeneracijom ili homeland generacijom, ali i anti-milenijalcima ${ }^{3}$. Procjenjuje se da ova generacija 2020. godine u SAD-u već obuhvaća oko 60 milijuna ljudi

\footnotetext{
1 Ekonomski fakultet Sveučilišta u Rijeci, e-mail: natasa.rupcic@efri.hr

2 Williams, A. (2015.) Move over, millennials, here comes generation Z, dostupno na: Move Over, Millennials, Here Comes Generation Z - The New York Times (nytimes.com) (pristup: 29.12.2020).

${ }_{3}$ Segran, E. (2016.) Your guide to generation Z: the frugal, brand-wary, determined anti-millennials, dostupno na: Your Guide To Generation Z: The Frugal, Brand-Wary, Determined Anti-Mi (fastcompany.com), (pristup 29.12.2020).

${ }^{4}$ Lanier, K. (2017.) 5 things HR professionals need to know about Generation Z: Thought leaders share their views on the HR profession and its direction for the future, Strategic HR Review, God. 16, Br. 6, str. 288-290.
} 
Otuda i veliki interes stručnjaka za istraživanjem značajki ove generacije. Tako se istražuju navike ovih ljudi, posebno one vezane za potrošnju, ali i njihove značajke vezane za zahtjeve radnih mjesta. Pritom se postavlja pitanje kako ova generacija može pridonijeti unaprjeđenju produktivnosti, efikasnosti, efektivnosti i održivosti, a posebno što je moguće učiniti, odnosno promijeniti kako bi se učinak ove generacije povećao. No, vrijedno je istražiti i koliko su značajke ovih ljudi, većinom određene razvojem informacijsko-komunikacijske (IK) tehnologije, usklađene sa zahtjevima suvremenoga poslovanja. Isto tako, korisno je utvrditi za koje vrijednosti se zalaže ili će se zalagati ova generacija, kakvu kulturu će izgrađivati, odnosno kakav stil vođenja će preferirati.

Treba imati na umu da se svaka generacija sastoji od ljudi koji međusobno intenzivno komuniciraju te donose vlastite ideje, perspektive i preferencije u svijet, a posebno na tržište rada. Poduzeća imaju određene uhodane procese te su u potrazi za kvalificiranom, ali i motiviranom radnom snagom spremnom na daljnje, osobito cjeloživotno učenje. Na mnogim tržištima rada takvih kandidata nedostaje, a poslodavci se, uz neodgovarajuće znanje, suočavaju i s nerealnim očekivanjima svojih mladih pripravnika ${ }^{5}$. Ovakve spoznaje posebno su važne za obrazovne institucije kako bi i ovu generaciju pripremili za tržište rada, ali im i pomogli da pronađu životni smisao i tako se samoaktualiziraju. Cilj ovoga rada je stoga istražiti značajke generacije $Z$ sa svrhom utvrđivanja upravljačkih praksi koje mogu dovesti do povećanja njihove učinkovitosti, ali i zadovoljstva i motivacije.

\section{Značajke i izazovi suvremenoga poslovanja}

Prije nego se analiziraju mogućnosti djelovanja i doprinos generacije $Z$ na tržištu rada, potrebno je identificirati značajke današnjega poslovanja u kojem moraju djelovati. Uvjeti u kojima djeluju suvremena poduzeća sve su složeniji. Zbog sve veće prevage ponude u odnosu na potražnju, sve težim postaje doprijeti do kupaca te ispuniti zahtjeve za visokim razinama profita. Suvremena poduzeća su tako prisiljena pronalaziti nove načine privlačenja kupaca kako bi tržišno realizirali svoju dodanu vrijednost. Složena tržišta 21. stoljeća zahtijevaju sposobnost brze i globalne dostave različitih kustomiziranih, kvalitetnih i ekološki prihvatljivih proizvoda koji se razlikuju ne samo po obliku ili funkciji, već i po pratećim uslugama. Upravljački procesi u fokusu imaju efektivnost, odnosno nastojanje da se stvaraju „prave stvari", odnosno one koje će se moći tržišno realizirati i imati prednost u odnosu na konkurenciju. Tako se ponuda neprestano usavršava i inovira na temelju učenja o svim sastavnicama procesa stvaranja vrijednosti: tehnologiji, resursima te odnosima s dionicima. No, dodana vrijednost koja će se tržišno realizirati također se nastoji stvoriti uz što niže troškove i u traženoj količini s obzirom na utrošak resursa. Stoga se istovremeno nastoje optimalizirati produktivnost, efikasnost i efektivnost.

Poslovanje u suvremenom, dinamičnom okruženju temelji se, prije svega, na učinkovitom korištenju informacija i znanja u svrhu inovativnoga stvaranja nove vrijednosti. Tome je razlog i visoki stupanj ovisnosti suvremenoga poslovanja o dosezima IK tehnologije, a koja zahtijeva značajna ulaganja. Tako se globalnim dosegom, odnosno ekonomijom obujma,

\footnotetext{
5 Šafránková, J. M. i Šikýř, M. (2017.) Work expectations and potential employability of millennials and postmillennials on the Czech labor market, Oeconomia Copernicana, God. 8, Br. 4, str. 585-599.
} 
nastoji smanjiti jedinični trošak, a time i cijena, što nadalje može osigurati globalnu dominaciju i održivu profitabilnost. Usto, IT platforme postale su nositeljice globalne ponude. Tako dolazi do razvoja tzv. „ekonomije na zahtjev” (engl. on-demand economy), odnosno ekonomske aktivnosti koja se temelji na zadovoljavanju potreba kupaca prema njihovim željama, najčešće trenutno, uz što kraću odgodu ili u željeno vrijeme. Mjesto susreta ponude i potražnje su tehnološka rješenja odnosno tzv. „aplikacije”. Ne samo što omogućuju veći stupanj kustomizacije, ove platforme omogućuju i značajno povećanje prodaje zbog lake dostupnosti i jednostavnosti korištenja. Čini se da je na ovaj način došlo do pomirenja dvije suprotne tendencije - masovne proizvodnje, koja označava i niže troškove/cijene, te kustomizacije, koja podrazumijeva više troškove/cijene. Globalna ekonomija na zahtjev tako osigurava kustomiziranu masovnu proizvodnju odnosno masovnu kustomizaciju.

Pri upravljanju odnosima s interesno-utjecajnim grupama važno je uspostavljati učinkovite partnerske odnose te ih neprestano razvijati. Pritom je od velike važnosti identificirati poželjne partnere. To su one interesno-utjecajne grupe koje raspolažu s potrebnim resursima ili kompetencijama. Suradnja između različitih entiteta kojom se može osigurati pristup resursima i kompetencijama tako postaje jedan od izvora konkurentskih prednosti suvremenih poduzeća. Stoga sve više jača važnost tzv. „ekonomije integracija“6. Upravljanje odnosima s interesno-utjecajnim grupama implicira razvoj tzv. "suradničkoga menadžmenta". Suradnički menadžment ima cilj identificirati, uspostaviti, održati i ojačati ekonomske odnose s kupcima, dobavljačima i drugim partnerima s komplementarnim sposobnostima i kapacitetima tako da se ciljevi poduzeća i partnera mogu ostvarivati na temelju utvrđivanja i implementacije zajednički prihvatljive strategije.

Suvremeni menadžment tako uključuje koprodukciju i razvijanje kulture suradnje, a ne nužno konkurentnosti. Treba konstatirati da je dominantna značajka globalne ekonomije koopeticija, odnosno istovremeno postojanje odnosa konkurentnosti i kooperacije (suradnje) između ključnih konkurenata ${ }^{7}$. Koopeticija podrazumijeva da partneri konkuriraju u jednom području poslovanja, a surađuju u drugom ili drugima. Poduzeća obično surađuju u aspektu razvoja novih proizvoda, odnosno u području istraživanja i razvoja, dok se natječu u drugim područjima poput nabave ili u drugim proizvodnim kategorijama. Tako, dok je suradnja česta u različitim procesima tijekom lanca stvaranja vrijednosti, aktivnosti koje su usmjerene prema razvijanju odnosa s kupcima obično su kompetitivne prirode ${ }^{8}$. Suradnja omogućuje korištenje zajedničke infrastrukture, dijeljenje rizika, znanja i najbolje prakse. Koopeticija tako ukazuje na visoko uvažavanje ne samo vlastitih, već i interesa druge strane. Na taj način dolazi do istinskoga rješavanja problema na način da se postiže „win-win“ ishod.

Učestalo se uspostavljaju i virtualne mreže ${ }^{9}$ koje se oblikuju ad hoc, kao privremene mreže poduzeća na nacionalnoj, ali i međunarodnoj razini koje su povezale trenutne, ali i promjenjive

\footnotetext{
${ }^{6}$ Walters, D.; Halliday, M. i Glaser, S. (2002.) Creating value in the „new economy", Management Decision, God. 40, Br. 8, str. 775-781.

7 Luo, Y. (2007.) A coopetition perspective of global competition, Journal of World Business, God. 42, str. 129-144.; Gnyawali, D. R.; He, J. i Madhavan, R. (2008.) Co-Opetition: Promises and challenges, U: Wankel, C. (ur.), 21st century management: A reference handbook, Thousand Oaks, Sage Publications, CA, str. 386-398.

8 Bengtsson, M. i Kock, S. (2000.) "Coopetition" in business networks - to cooperate and compete simultaneously, Industrial Marketing Management, God. 29, Br. 5, str. 411-426.

9 Davidow, W. H. I Malone, M. S. (1992.) The Virtual Corporation, Harper Collins, New York, NY.
} 
prilike i okolnosti. Pritom dolazi do razmjene i zajedničkoga korištenja različitih resursa, posebice znanja te osiguravanja zajedničkoga pristupa tržištima. Djelovanje virtualnih mreža omogućuje IK tehnologija koja olakšava usklađivanje djelovanja poslovnih i drugih sustava u stvarnom vremenu. Što je stupanj suradnje veći, to je teže odrediti gdje jedno poduzeće započinje, a drugo završava, a zajedno s drugima tvore složene poslovne ekosustave. Integralni i koordinirani pristup znanju, tehnologiji i partnerima stoga postaje ključni čimbenik uspjeha.

Poslovanje obilježava visoki stupanj interdisciplinarnosti u smislu sinergijskih učinaka različitih disciplina poput psihologije, sociologije, menadžmenta, informatike i drugih. Ljudsko djelovanje se općenito sve više temelji na tzv. "triple helix" modelu, odnosno modelu trostruke uzvojnice, što podrazumijeva suradnju gospodarstva s javnim sektorom i akademskom zajednicom, posebno na temelju tzv. "pametne specijalizacije". Na ovaj model se nadovezuje tzv. "quadruple helix" model ${ }^{10}$ ili model četverostruke uzvojnice koji ukazuje na uključivanje četvrte komponente - medija i civilnoga društva u procese razvoja vrijednosti koja odgovara potrebama društva. Ovaj model je nastao kao odgovor na činjenicu da neke tehnologije u nastajanju sasvim ne odgovaraju potrebama društva, što ograničava njihov mogući utjecaj. Ovim modelom posebno se naglašava važnost društvene odgovornosti. Sveučilišta se posebno potiče da razvijaju svijest o važnosti društvene odgovornosti kako bi se takve vrijednosti lakše prenijele u društvo. U svrhu postizanja održivoga života lokalnih zajednica i planeta u cjelini razvijen je i tzv. "quintuple helix" model" ili model peterostruke uzvojnice koji uključuje i aspekt prirode odnosno prirodnoga okruženja.

Svrha ovih modela je postići proces generiranja i razmjene znanja te tako pridonositi održivom razvoju na temelju učenja, inoviranja i suradnje svih uključenih dionika. Jasno je da ovakvo djelovanja od svih uključenih dionika, pa tako i od nove generacije, podrazumijeva intenzivan razvoj njihovih tehničkih, ali i društvenih i koncepcijskih vještina. Stručne ili tehničke vještine se odnose na sposobnosti obavljanja određenih zadataka na temelju znanja kojim osoba zna koristiti tehniku, tehnologiju, alate, metode itd. ${ }^{12}$ Stječu se formalnim obrazovanjem te usavršavaju praksom. Socijalne ili interpersonalne vještine odnose se na sposobnost pojedinca da radi zajedno s drugima u smislu umrežavanja s drugim ljudima, timskoga rada, učinkovitoga primanja i davanja informacija, rješavanja sukoba, pregovaranja te vođenja i motiviranja drugih. S obzirom na intenzivnu interakciju s velikim brojem dionika, socijalne vještine prerastaju u vještine upravljanja odnosima ${ }^{13}$. Koncepcijske vještine se odnose na sposobnost analize problema te sinteze zaključaka u svrhu dizajniranja rješenja. Tako je problem važno sagledati sustavski, u odnosu na širi sustav i s obzirom na sve elemente sustava kako bi se utvrdila priroda odnosa te implikacije problema, ali i utjecaj rješenja na sve elemente sustava, odnosno na sve uključene dionike. To je važno i zbog toga što neka situacija može imati dugoročne implikacije koje ne moraju biti odmah očite, ali ih je moguće identificirati pažljivim razmatranjem problema korištenjem sustavskoga pristupa. Tako je na temelju simulacije moguće identificirati rješenje koje može integrirati različite

\footnotetext{
${ }^{10}$ Carayannis, E.G. i Campbell, D.F.J. (2009.) 'Mode 3' and 'Quadruple Helix': toward a 21st century fractal innovation ecosystem, International Journal of Technology Management, God. 46, Br. 3/4, str. 201-234.

${ }^{11}$ Carayannis, E.G.; Barth, T.D. i Campbell, D.F.J. (2012.) The Quintuple Helix innovation model: global warming as a challenge and driver for innovation, Journal of Innovation and Entrepreneurship, God. 1, No. 1, doi:10.1186/2192-5372-1-2

12 Rupčić, N. (2018.) Suvremeni menadžment - teorija i praksa, Ekonomski fakultet Sveučilišta u Rijeci, Rijeka.

$13 \mathrm{lbd}$.
} 
perspektive. To podrazumijeva visoki stupanj inteligencije, široki spektar znanja i iskustva, ali i entuzijazam za suočavanje sa složenim i neizvjesnim situacijama. U nastavku je potrebno razmotriti je li generacija $Z$ na tragu ovih zahtjeva.

\section{Usklađenost značajki post-milenijalaca sa značajkama suvremenoga djelovanja i poslovanja}

Generacija Z rasla je u uvjetima globalne recesije, ali i dominacije IK tehnologije s kojom se susreću od rođenja. Tako ovu generaciju ne čine samo tzv. "digital natives", već i tzv. "mobile natives", odnosno osobe koje se s tehnologijom, a zbog razvoja mobilnih uređaja, služe „u pokretu“. Navikli su na činjenicu da im je sve dostupno i moguće jednim klikom, što se očituje i u njihovom pristupu učenju i radu. Njima je, također, komuniciranje putem tzv. „društvenih mreža" temeljni način druženja. Stoga ovoj generaciji nedostaju društvene vještine u neposrednoj komunikaciji ${ }^{14}$. lako im je sve dostupno i uvjerava ih se da mogu postati što god žele, utvrđeno je da oni ne znaju definirati, odnosno izraziti svoje želje i aspiracije ${ }^{15}$, iako prema svom životu i radu imaju visoka očekivanja. Tako se ne znaju ni prezentirati na pravi način, što, uz manjak stručnih vještina, poslodavce navodi da zapošljavaju iskusnije, odnosno starije kandidate čija su očekivanja realnija ${ }^{16}$.

S obzirom na njihovu veliku usmjerenost na IK tehnologiju, posebno mobilne uređaje, jedna od ključnih značajki post-milenijalaca je manjak koncentracije, odnosno usredotočenosti. Ova je pak tehnologija pod utjecajem neprestanih promjena, odnosno unaprjeđenja. Tako se neprestano pojavljuju mogućnosti nadogradnje (engl. update) postojećih softverskih rješenja ili njihove izmijenjene verzije, ali i nova rješenja koja omogućuju nove ili drugačije mogućnosti korištenja. Osim toga, mobilni uređaji nude goleme količine različitih sadržaja koje imaju značajke zanimljivosti, novosti, korisnosti ili kombinacije ovih karakteristika. Ova generacija informacijske sadržaje tako konzumira brže nego ijedna prije. Sve te sadržaje nemoguće je istovremeno i pregledati i kritički razmotriti, posebno ako osobama nedostaje prethodnoga znanja i/ili iskustva. Tako mlade osobe raspoložive sadržaje pretražuju stihijski, konzumiraju ih površno te brzo gube interes budući da se neprestano pojavljuju novi sadržaji. Njihov raspon pozornosti se tako još više smanjio u odnosu na raspon pozornosti prethodne generacije. Prema jednom istraživanju ${ }^{17}$, čak trećina pripadnika generacije Z priznala je da im manjka fokus, odnosno sposobnost usredotočenja. U skladu s tim, njihova orijentacija je primarno pragmatična, odnosno usmjerena je na traženje neposredne korisnosti u informacijskom sadržaju koji konzumiraju u smislu neposredne primjene ili zabave. S druge strane, budući da se djelovanje mobilnih aplikacija uvelike temelji na načelima rada kockarnica, odnosno usmjereno je na neprestano davanje podražaja koje uzrokuje ugodu te na obećanje daljnje ugode u slučaju daljnjega korištenja, post-milenijalnci, više nego njihovi

\footnotetext{
14 Šafránková, J. M. i Šikýř, M. (2017.) Work expectations and potential employability of millennials and postmillennials on the Czech labor market, Oeconomia Copernicana, God. 8, Br. 4, str. 585-599.

15 Darrisaw, A. (2017.) Millennials Want to Chase Their Passions But Can't Communicate What They Are, dostupno na: (1) Millennials Want to Chase Their Passions But Can't Communicate What They Are | Linkedln (pristup: 30.12.2020).

16 Šafránková, J. M. i Šikýr̆, M. (2017.) op. cit.

17 Schawbel, D. (2014.) Gen Y and Gen Z global workplace expectations study, dostupno na: Gen Y and Gen Z Global Workplace Expectations Study | Workplace Intelligence (pristup 29.12.2020).
} 
prethodnici, iskazuju znakove ozbiljne ovisnosti o takvim uređajima i njihovim sadržajima, što ih odvraća od učenja, a posebno od kritičkoga promišljanja raznih pojavnosti.

Smanjen raspon pozornosti post-milenijalaca u izravnoj je povezanosti s povećanjem njihove sposobnosti istovremenoga obavljanja raznih aktivnosti (engl. multitasking). Tako milenijalci i post-milenijalci, ali i sve osobe koje su se novim okolnostima dobro prilagodile, istovremeno pretražuju sadržaje na internetu, kreiraju vlastiti sadržaj u okviru radnih zadataka ili za zabavu, primaju informacije s digitalnoga radijskog i TV programa ili putem YouTube aplikacije te se dopisuju putem neke od chat aplikacija. Na taj je način njihovo djelovanje prepuno sadržaja koji im odvlači pozornost te se prebacuju s jednoga sadržaja na drugi. Pritom se gubi granica između aktivnosti koje se mogu podijeliti na posao ili zabavu. Treba također spomenuti da prilikom praćenja sadržaja vezanih za vijesti, a koje u najvećoj mjeri prate putem društvenih mreža, nova generacija manju pozornost posvećuju točnosti sadržaja, a veću njegovom zabavnom aspektu i mogućnosti interakcije ${ }^{18}$.

Post-milenijalci su svjesni raspoloživosti informacija te više cijene mogućnost pristupa informacijama bilo gdje i bilo kada nego vlastito raspolaganje s njima, odnosno vlastito znanje. Pritom ih kratak raspon pozornosti odvraća od klasičnih oblika školovanja koji od njih zahtijevaju pozornost, disciplinu te usredotočenost na zadatke višega stupnja složenosti. Usto, više su zainteresirani za praktične aktivnosti, što znači da su skloni istraživati opcije vlastitoga razvoja kroz rad i učenje istodobno. To znači i da su više skloni pratiti tečajeve koje su nude u digitalnome obliku, posebno one kojima je moguće pristupiti prema vlastitim vremenskim i kognitivnim mogućnostima i ograničenjima. Takav način učenja privlačan im je također zbog nižih troškova, odnosno manje potrebe za zaduživanjem.

Ovakav način razmišljanja o vlastitom razvoju zanimljiv im je i zbog želje za brzom zaradom kakva je moguća putem medija poput YouTubea ili društvenih mreža. Pa ipak, iako generacije Y i Z imaju visoku sklonost mrežnom poduzetništvu, ove dvije grupe iskazale su i veći strah od neuspjeha zbog mogućnosti korupcije i financijskoga tereta ${ }^{19}$. Treba napomenuti da ovakav način razmišljanja i djelovanja post-milenijalaca proizlazi i iz visokoga stupnja njihove individualnosti. Zbog intenzivne usmjerenosti na IK tehnologiju smatraju se drugačijima od drugih generacija, posebno starijih, koje imaju manje interesa upoznavati, u čemu ih priječi i nizak raspon pozornosti. Tako su u učenju i radu više individualno orijentirani ili se pak povezuju s pripadnicima vlastite generacije. Ova činjenica također ih potiče na poduzetništvo, posebno na stvaranje tzv. „poduzeća u nastajanju“ (engl. start-ups) budući da rad u velikim organizacijama i korporacijama podrazumijeva veći stupanj poštivanja procedura i pravila, što znači manjak slobode, ali i obavezu ponašanja kakvo je predviđeno u određenim okolnostima.

Ove značajke mogu se dovesti u vezu s višim očekivanjima ove generacije od života $i$ okruženja. S obzirom na globalizaciju i dostupnost informacija iz svih krajeva svijeta, postmilenijalci imaju veće očekivanje od svoga života, ali i očekuju da će više doprinijeti svijetu. No, nizak raspon pozornosti potiče ih da takav učinak žele što prije. Isto tako, u radu s

\footnotetext{
18 Gentilviso, C. i Aikat, D. (2019.) Embracing the Visual, Verbal, and Viral Media: How Post-Millennial Consumption Habits are Reshaping the News, U: Schulz, J.; Robinson, L.; Khilnani, A.; Baldwin, J.; Pait, H.; Williams, A.A.; Davis, J. i lgnatow, G. (ur.) Mediated Millennials (Studies in Media and Communications, Vol. 19), Emerald Publishing Limited, pp. 147-171.

19 ... (2014): Hrvati ipak imaju pozitivan stav o poduzetništvu? Dostupno na: Hrvati ipak imaju pozitivan stav o poduzetništvu? (lider.media), (pristup 30.12.2020.)
} 
drugima, povratne informacije žele odmah, kao i pomoć ili podršku i to sve više u osobnoj komunikaciji ${ }^{20}$. Isto tako, ako se ciljevi ne ostvaruju brzo, smatraju da nešto nije u redu i skloni su odustati. Očekuju podršku od strane organizacije, dok sami ne iskazuju visoki stupanj vjernosti kako prema ciljevima, tako i prema organizacijama. Pritom se rukovode vlastitim željama, potrebama i ambicijama te razvijaju visoku individualnost, što ih onemogućuje u uspostavljaju jačih veza s drugima.

Odnos prema radu se nesumnjivo promijenio pod utjecajem velike količine podražaja kojem su pojedinci izloženi. Tako, umjesto stava da je karijera nešto što se gradi i izgrađuje godinama, mladi traže posao koji će im odmah potpuno odgovarati, pružiti im osjećaj smisla, riješiti problem dosade i pružati uzbuđenje i zadovoljstvo. Stoga su skloni jednostrano pristupati traženju posla, odnosno tražiti samo ono što njima trenutno odgovara bez obzira na vlastita ograničenja i potrebu daljnjega razvoja. Tako nerijetko "skaču“ s jednoga posla na drugi, odnosno od trenutne prilike do iduće trenutne prilike ${ }^{21}$. Jedan od razloga takvom pristupu je i dinamika u poduzetništvu: poduzeća se osnivaju, transformiraju, prodaju i nestaju brže nego ikada, što ljudima daje osjećaj da nije korisno ulagati u razvoj poduzeća i razvijati dugoročnu predanost. Ovaj problem je moguće rješavati jedino ako obje strane iskažu ozbiljnost svojih razvojnih namjera. S jedne strane poduzeće, odnosno menadžment, treba iskazati viziju poslovanja koja zaposlenicima može dati osjećaj smisla i vlastite svrhovitosti. Potom i zaposlenici rad na ostvarenju takve vizije trebaju shvatiti kao dugoročni proces izgrađivanja vlastitih znanja i vještina, ali i osobnoga razvoja, odnosno samoaktualizacije kroz rad. Program mentorstva u tom procesu može biti od velike koristi, što je u skladu s činjenicom da je $51 \%$ ispitanih pripadnika ove generacije iskazalo preferencije prema komunikaciji licem u lice s njihovim menadžerima u odnosu na slanje poruka i video poziva, a vezano za očekivanja na radnom mjestu ${ }^{22}$. No, $i$ to se može dovesti u vezu sa smanjenjem njihova raspona pozornosti, što ih onemogućuje $u$ praćenju veće količine stručnoga teksta ili uputa, posebno ako nisu pisani u natuknicama.

S obzirom na dosege IK tehnologije, post-milenijalci su orijentirani globalno. Tako su izloženi utjecaju s raznih strana svijeta. Pritom se mogu povezivati s različitim ljudima, ovisno o uzajamnim željama. Društvene mreže ovoj generaciji omogućile su da se povezuju s ljudima različitih kultura i podrijetla, sve dok dijele zajedničke interese. Utvrđeno je također da oni iskazuju više poduzetničkih aspiracija te želje za zapošljavanjem drugih. Tako je istraživanjem utvrđeno da $17 \%$ pripadnika generacije $Z$ ima takve aspiracije prema $11 \%$ milenijalaca $^{23}$. Međutim, globalni utjecaji su također različiti, imaju svoje razloge koji nisu odmah vidljivi te podrazumijevaju predanost i visoki stupanj razumijevanja različitih relacija. S obzirom na prethodne značajke, post-milenijalci za ovakve silnice iskazuju veliki interes, usmjereni su samo na pozitivnu stranu takvih manifestacija, ali nisu uvijek u mogućnosti apsorbirati mnoštvo različitosti te ih kanalizirati prema konkretnim aktivnostima. No, spremnost na prihvaćanje globalnih upliva post-milenijalce čini prilagodljivijima prihvaćanju raznolikosti i različitosti. Isto tako, ovakvi utjecaji čine im rani ulazak na tržište rada vrlo privlačnim, iako je tu riječ o različitim ugovornim odnosima privremene prirode (engl. freelancing).

\footnotetext{
20 Schawbel, D. (2014.), op. cit.

${ }^{21}$ Ignatius, A. (2016), What CEOs Really Worry About, dostupno na: https://hbr.org/2016/11/the-best-performingceos-in-the-world, (pristup 29.12.2020.)

22 Schawbel, D. (2014.) op. cit.

$23 \mathrm{Ibd}$.
} 


\section{Uloga nove generacije u suvremenom poslovanju}

Može se konstatirati da je veliki interes za razlikama između generacija prije svega motiviran željom za identificiranjem njihovih navika kako bi se na taj način moglo utjecati na njihove navike potrošnje. Pritom, čini se, temeljna razlika između generacija proizlazi iz njihovoga određenja prema IK tehnologiji. Dok za starije generacije računala, tableti i mobiteli mogu predstavljati alat kojim mogu postići neke ciljeve, kod novijih generacija takva tehnologija predstavlja sastavni dio njihove osobnosti i način života s kojom se u potpunosti identificiraju i stapaju, uz zanemarivanje ranije dominantnih životnih aspekata poput druženja uživo ili razmišljanja o svrsi raznih aktivnosti i samoga života. U svijetu neprestanih podražaja naprosto nema prostora ni vremena za razmišljanje. Tako je proučavanje razlika između generacija, što je dobilo na popularnosti posljednjih godina, jednostavno uzrokovano željom njihova što boljega iskorištavanja u svrhu zarade, a ne u svrhu identificiranja devijacija od ljudske prirode radi njihova ispravljanja u svrhu povećanja društvenoga razvoja, ali i osobnoga ispunjenja.

Pritom se čini da ostali subjekti nastoje podržati tendenciju ovisnosti mlade generacije koja je stvorena lakom dostupnošću elektroničkih sadržaja. Stoga je, a kako bi se maksimizirala zarada, potrebno identificirati njihove navike korištenja društvenih mreža te konzumacije audio i video sadržaja kako bi se kroz te kanale promovirali razni sadržaji u svrhu povećanja prodaje. Tako, umjesto da se mlada generacija odvlači iz virtualnoga u stvarni život, odnosno u relacije raznih entiteta u neposrednom okruženju kada bi osobe mogle primiti potpuni podražaj različitim osjetilima, suvremeno društvo je usmjereno na produbljivanje virtualnih sadržaja kojima se kopira stvarni svijet te mu se dodaju svi čimbenici koji bi mogli povećati njihovu atraktivnost pa se virtualna i proširena stvarnost proglašavaju korisnijima i važnijima za život suvremenoga čovjeka od stvarnoga života koji je sporiji, a time i dosadniji. Štoviše, ljude se pozicionira u ulogu receptora, odnosno primatelja pažljivo promišljenih sadržaja koji imaju ulogu povećati vezanost, odnosno ovisnost i repetitivnost akcija bez razmišljanja, a na temelju izrazito kratkoročnoga pamćenja. Pritom treba konstatirati da su postmilenijalci, zbog neprestanoga bombardiranja podacima te kratkoga raspona pozornosti, neprestano gladni novih sadržaja. Isto tako, sve što traže mora biti cool, te izazivati osjećaje uzbuđenja i ugode, odnosno podrazumijevati snažan podražavajući emocionalni kapital. S tim u vezi je i činjenica da post-milenijalci, radi dosade koja se javlja nakon svakoga podražaja, neprestano traže nova uzbudljiva i ugodna iskustva. Stoga se proizvodi transferiraju u proizvod-usluge te se aspektu usluga pridaje veća pozornost nego značajkama proizvoda. Drugim riječima, značajke proizvoda se predstavljaju senzacionalnima, iako već nakon kratkoga vremena slijedi nova, još senzacionalnija inačica, praćena uzbudljivim pristupom u pratećim uslugama. Tako se podaci o korištenju mobilnih uređaja od strane post-milenijalaca više sati dnevno ne smatraju zabrinjavajućima, već se proglašava čudesnim dosegom mlade i perspektivne generacije, nedokučivom starijima. Međutim, na ovaj način mlada generacija preuzima pasivnu, konzumerističku ulogu, lišenu značajnije kreacije.

Treba također napomenuti da se razlike između generacija najvećim dijelom pojavljuju pod utjecajem vanjskih čimbenika. To su primarno ekonomska kretanja (razdoblja intenzivnoga rasta ili krize i recesije) te razvoj tehnologije, posebno one koja je primjenjiva u svakodnevnom životu, odnosno danas IK tehnologije. Tako, dok će generacija rođena u vrijeme recesije uvidjeti važnost štednje i ulaganja u obrazovanje, generacija rođena u vrijeme 
prosperiteta, a pod utjecajem IK tehnologije, bit će sklona tražiti sadržaje koji pojačavaju osjećaje ugode i zabave. Tako treba konstatirati da će generacija izložena prosperitetu i ugodi trenutne dostupnosti elektroničkih sadržaja, uključivo online shopping, biti manje sklona razvoju vještina koncepcijskog razmišljanja i traženju rješenja sustavskom pristupom. Tako se može očekivati da će rezultati takve generacije biti ekonomski lošiji, što će dovesti do prevage utjecaja ekonomskih čimbenika u oblikovanju značajki iduće generacije. Na taj način sustav može održati ravnotežu, posebno razvojnu ravnotežu. No, s obzirom na trendove u smislu lake dostupnosti svih sadržaja, potaknute i razvojem ekrana na dodir, ostaje pitanje koliko će buduće generacije (npr. alfa) biti spremne potruditi se da ostvare neke rezultate i ciljeve. Uz uvjet da budu znali kako ih odrediti.

\section{Upravljanje ljudskim potencijalima: generacija Z}

Današnje nove generacije na radnom mjestu će ipak trebati surađivati s pripadnicima drugih generacija, budući da je neki oblik intergeneracijske raznolikosti u većini slučajeva logično očekivati. To je posebno važno s aspekta potrebe učenja i razmjene znanja kao uvjeta inoviranja dodane vrijednosti. Pritom se činjenica postojanja intergeneracijske raznolikosti može smatrati prednošću u smislu mogućnosti razmatranja različitih perspektiva rješavanja problema, posebno kada je riječ o traženju tzv. „integracijskih rješenja“. Istraživanja su pokazala da se pripadnici različitih generacija ipak razlikuju s obzirom na vrijednosni sustav i stavove, posebno sa stajališta komuniciranja i procesa učenja ${ }^{24}$. No, suradnja između različitih generacija od iznimne je važnosti te njome treba pažljivo upravljati kako bi se izbjegao gubitak postojećega znanja, odnosno tzv. ,knowledge crash" ${ }^{\prime 25}$, što je posebno izgledno za tzv.,"neopipljivo znanje“, odnosno znanje i vještine koji se mogu prenositi mentorstvom ili oponašanjem. Međutim, budući da generacija Z ima tendenciju uvoditi tehnološka rješenja u svrhu jačanja produktivnosti, u razmjenu informacija i znanja na taj se način ipak mogu uključiti svi bez obzira na generacijsku pripadnost, što predstavlja potencijal za razvoj integracijskih rješenja. Pritom se mogu pojaviti brojni problemi poput onoga vezanog za curenje informacija i znanja. Naime, nove generacije pod utjecajem brzo-mijenjajućih silnica iz okruženja ne razvijaju visoki stupanj odanosti prema organizaciji, već njeguju individualizam. Individualizam zajedno s orijentacijom na intenzivno korištenje IK tehnologije, posebno tzv. „društvenih mreža“, može dovesti do namjernoga ili nenamjernoga curenja informacija. Takvo namjerno ponašanje mladi ljudi mogu smatrati i načinom osiguranja vlastite trajnije zapošljivosti. Stoga menadžment posebnu pozornost treba posvetiti identifikaciji informacija i znanja koje treba zaštititi kao poslovnu tajnu.

S obzirom na aspekt učenja i razmjene znanja, mogu se pojaviti razlike između generacija koje mogu biti stvarne ili dio usađenih mentalnih modela na temelju kojih se osobe ponašaju reaktivno. Tako stariji zaposlenici mlađe mogu a priori smatrati površnim i rastresenim osobama koje ne mare za organizacijske vrijednosti i norme ponašanja, dok mlađi mogu starije a priori smatrati nefleksibilnima i nevoljnima dijeliti informacije i znanje. Zbog toga je moguće očekivati probleme prilikom primjene metode bihevioralnoga modeliranja kao metode koju

${ }^{24}$ Ebrahimi, M.; Saives, A. L. i Holford, W.D. (2008.) Qualified ageing workers in the knowledge management process of high-tech businesses, Journal of Knowledge Management, God. 2, Br. 12, pp. 124-140.

${ }^{25}$ Ermine, J.L. (2010.) Knowledge crash and knowledge management, International journal of knowledge and systems science, God. 1, Br. 4, str. 79-95. 
su Urick i Sprinkle 26 identificirali kao najkorisniju za potrebe prijenosa neopipljivoga znanja novim zaposlenicima, kao što su, primjerice, organizacijske vrijednosti. Tako je moguće posegnuti za učenjem posredstvom tehnologije kao što su webinari, podcast sadržaji te sadržaji koji predstavljaju tzv. „obrazovnu zabavu“ (engl. edutainment). Edutainment podrazumijeva igranje poslovnih igara, što sudionicima omogućuje izlaganje zadacima i ponašanju koje je potrebno za određene zadatke ${ }^{27}$. S obzirom na kratak raspon pozornosti mlađih generacija, ova metoda može polučiti željene rezultate jer uspijeva održati pozornost korisnika zabavnim sadržajima. Tako mlađe generacije mogu vježbati odlučivanje u kontroliranim uvjetima. No, nije svako znanje moguće prenositi na ovaj način. Dok je zabavnim simulacijama većinom moguće prenijeti eksplicitno znanja, za prijenos implicitnoga znanja potrebno je primijeniti druge metode, poput promatranja (engl. job shadowing) i mentorstva ${ }^{28}$.

Bez obzira na preferencije, pripadnici svih generacija trebaju imati cilj razvijati tzv. "učeću agilnost", koja podrazumijeva potpunu pozornost na određeni sadržaj, a može ju se postići i metodom interne mobilnosti. Moguće je identificirati različite razine učenja na temelju Batesonove teorije učenja ${ }^{29}$. Tako se razina nultoga učenja (LO) može postići na način da se novoga zaposlenika stavlja u neku situaciju te se očekuje uvijek isti odgovor na podražaj te situacije. Ta metoda je korisna kada se od novoga zaposlenika očekuje da nauči određeno ponašanje. Tako se situacije neprestano ponavljaju kako bi sudionik razvio automatizam odgovora te na taj način razvio „profesionalne reflekse“. Rotiranjem po raznim odjelima novi zaposlenik može naučiti različite oblike ponašanja koje zahtijeva određena praksa. Na taj način kod novoga zaposlenika se razvija šira slika o djelovanju organizacije kako bi uočili kako je pozicioniran njihov djelokrug posla. $U$ ovom procesu očekuje se intenzivna suradnja između starijih i novih, redovito mlađih zaposlenika u kojem stariji mlađe mogu učiti disciplini i fokusiranosti.

Budući da je malo zadataka danas strogo repetitivne prirode, učenje nulte razine nije moguće strogo odvojiti od učenja prve razine (L1). Tako su za obavljanje većine zadataka potrebni neko znanje i vještine, ali i određeni stav i pristup, odnosno ponašanje. I u ovom obliku učenja moguće je primijeniti internu mobilnost. Mladi zaposlenici na taj način mogu učiti o različitim pristupima radu te prema tome prilagoditi svoje ponašanje. Na ovaj način mladi zaposlenici mogu uvidjeti i razloge zašto se neki oblik ponašanja primjenjuje, odnosno zašto je neki pristup bolji od drugoga.

Mlade zaposlenike potrebno je izložiti i koristima učenja druge i treće razine. Učenje druge razine (L2) odnosi se na učenje kako učiti. Na taj način pojedinac, uz usvajanje raznih znanja i vještina, uči primijeniti i kritičko razmišljanje, odnosno kritičku refleksiju, što dovodi do spoznaje o koristima određenih vrsta znanja, vještina, ali i vrijednosti i pristupa. Na taj način pojedinac uči kako primijeniti kontingencijski pristup. S obzirom na iskustvo, ključno je

\footnotetext{
${ }^{26}$ Urick, M. i Sprinkle, T. (2018.) Three Generational Issues in Organizational Learning: Knowledge Management, Perspectives on Training, and "Low-stakes" Development, The Learning Organization, God. 25, Br. 1, str. $102-112$.

27 Kapp, K.M. (2012.) The Gamification of Learning and Instruction: Game-based Methods for Training and Tducation, Pfeiffer, San Francisco, CA.

${ }^{28}$ Warhurst, R.P. i Black, K.E. (2015.) It's never too late to learn, Journal of Workplace Learning, God. 27, Br. 6, str. 457-472.

29 Bateson, G. (1972.) Steps to an Ecology of Mind, Chicago University Press, Chicago, Il.; Janand, A. i Notais, A. (2018.) Learning on the Move A Reassessment of Mobility through the Lens of Bateson's Learning Theory, The Learning Organization, God. 25, Br. 1, str. 113-122.
} 
da stariji zaposlenici mlađima usade spoznaju o važnosti kritičkoga razmišljanja kako ne bi padali u zamke prvoga dojma koji podupire njihove prethodne spoznaje.

Ovaj oblik učenja logički se nadovezuje na učenje treće razine (L3) kada pojedinac uči učiti o sebi kroz proces samo-refleksije i preispitivanja kako bi utvrdio koje mentalne modele ima, jesu li oni prikladni te kako ih transformirati. Na ovaj način pojedinac razvija i vlastitu viziju daljnjega razvoja te pridonosi stvaranju vlastite kreativne tenzije koja ga potiče prema realizaciji te vizije. lako je ova praksa važna za sve generacije, posebno je korisno temeljima ovakve prakse naučiti mlade generacije. Na ovaj način moguće je povećati raspon njihove pozornosti, strpljivost, ali i sklonost suradnji i daljnjem učenju. Za ovaj proces ključno je primijeniti metodu mentorstva, pri čemu mentor može djelovati kao savjetnik, ali i kao osoba koja pomaže u procesu odlučivanja, odnosno olakšava ga.

Posebnu pozornost potrebno je posvetiti vođenju pripadnika ove generacije. Tako treba imati na umu da ovu generaciju pokreću vrijednosti poput društvene pravednostij ${ }^{30}$. To istovremeno znači i veći stupanj uključivosti radne snage, odnosno jednak tretman bez obzira na kulturalne, spolne ili rasne razlike, što pripadnici ove generacije očekuju na radnom mjestu. Umjesto novca, ali i raznih beneficija, što je više motiviralo prethodne generacije, ova generacija očekuje ekonomsku sigurnost i mogućnost napredovanja na poslu ${ }^{31}$, odnosno brinu ih pitanja vlastita opstanka. Više od polovice ispitanih smatra da je iskrenost najvažnija značajka vođe, a očekuju i jasnu viziju kao i dobre komunikacijske sposobnosti ${ }^{32}$. Čini se da na taj način dolazi do konvergencije vrijednosti u odnosu na prethodne generacije jer je također uočeno da generacija $\mathrm{Z}$ u odnosu na generaciju $\mathrm{Y}$ ima manju sklonost multitaskingu te radu u brzom i dinamičnom okruženju, ali i veću sklonost stabilnosti zaposlenja ${ }^{33}$.

Istraživanje na uzorku studenata u Češkoj pokazalo je da očekivanja nove generacije od posla ipak nisu pretjerana. Tako u svojoj karijeri očekuju smisleni rad (80\%), samoaktualizaciju (70\%), prijateljsko radno okruženje (66\%), pravedne kompenzacije $(63 \%)$, sigurnost posla (54\%), profesionalni menadžment (43\%) te osobni razvoj (43\%) ${ }^{34}$. No, treba ukazati i na činjenicu da je na uzorku studenata u Češkoj utvrđeno da čak $69 \%$ studenata ekonomskih fakulteta žele postati menadžeri ${ }^{35}$. Također imaju visoka očekivanja o plaći. Tako je $57 \%$ studenata u istom istraživanju izjavilo da očekuju pripravničku plaću između 750 i 1.050 eura uz statistički značajnu razliku u korist studenata u odnosu prema studenticama, te smatraju da će im sama diploma to omogućiti, dok je prosječna bruto plaća u tom razdoblju bila oko 1.107 eura. Može se zaključiti da pripadnici generacije $Z$ zaboravljaju da je put do razvoja karijere i viših pozicija dug i podrazumijeva razvoj raznih znanja i vještina. Također zaboravljaju da plaća ovisi o doprinosu, odnosno o produktivnosti, na što im treba posebno ukazati.

\footnotetext{
${ }^{30}$ Meehan, M. (2016.) The next generation: what matters to gen we, dostupno na: The Next Generation: What Matters To Gen We (forbes.com) (pristup 29.12.2020.).

31 Schawbel, D. (2014.) Gen Y and Gen Z global workplace expectations study, dostupno na: Gen Y and Gen Z Global Workplace Expectations Study | Workplace Intelligence (pristup 29.12.2020).

$32 \mathrm{lbd}$.

33 Ibd.

34 Šafránková, J. M. i Šikýř, M. (2017.) op. cit.

$35 \mathrm{Ibd}$.
} 


\section{Zaključak}

Za niti jednu generaciju ne može se tvrditi da je u potpunosti monolitna, odnosno da ima značajke koje je u potpunosti dijele od drugih generacija. No, kako se mijenja kultura i društvo, mijenjaju se i značajke ljudi koji intenzivnim komuniciranjem zbog generacijske povezanosti oblikuju nove obrasce ponašanja i djelovanja. Generaciju Z primarno oblikuje neprestano korištenje IK tehnologije. No, menadžeri, ali i stručnjaci koji definiraju obrazovne politike, trebaju uzeti u obzir činjenicu da informacijska dostupnost ne znači da mladi ljudi mogu utvrditi što žele i u čemu mogu biti dobri. Za to je potrebno vrijeme i zajednički, mentorski rad na procesuiranju informacija, ali i emocija, te otkrivanju talenata. Stoga se može zaključiti da je s mladim ljudima potrebno raditi više, a ne manje, i to što je moguće više neposredno, kako bi prošli put samospoznaje i samorazvoja. Toga moraju biti svjesni i menadžeri u poduzećima te pripravnicima ponuditi niz programa u tom smislu. No, također je korisno pripremiti jasno strukturirane zadatke te jasne uloge i granice koje pripravnicima mogu omogućiti osjećaj vlastitoga postignuća u određenom kontekstu. Pomoć i podrška starijih kolega u tom smislu također je vrlo važna. Kako su pripadnici ove generacije navikli na pristup svim informacijama, to je potrebno osigurati i u poduzeću, odnosno primijeniti tzv. „menadžment otvorene knjige“. No, kako je informacije teško razumjeti bez prethodne obuke, potrebno je osigurati i takve programe prije davanja pristupa informacijama. Na taj je način mladim generacijama također korisno ukazati na njihovu ulogu u sustavu, odnosno na njihov očekivani doprinos, ali i na mogućnosti razvoja.

I generaciji $Z$ je u radu potrebno osigurati sve uvjete, ali i znanje i vodstvo, kako bi ih se moglo opunomoćiti, odnosno osigurati im viši stupanj autonomije u radu, a time i inoviranje. $\mathrm{Na}$ taj način, odnosno ukazivanjem na važnost neprestanoga učenja i razvoja, moguće je postići visoki stupanj zadovoljstva poslodavaca i zaposlenika nove generacije. Jasno je pritom da se uzajamno zadovoljstvo može temeljiti samo na realnom i primjerenom doprinosu, a to je činjenica koja vrijedi za pripadnike svih generacija. Tako se može pretpostaviti da će se negativne značajke ove generacije s vremenom ipak prigušiti i otvoriti prostor razvoju onih pozitivnih. Stoga je, također, korisno više se usredotočiti na pojedince i njihove snage i slabosti, a ne na generacijske stereotipe.

\section{LITERATURA}

1. Bateson, G. (1972.) Steps to an Ecology of Mind, Chicago University Press, Chicago, II.

2. Bengtsson, M. i Kock, S. (2000.) "Coopetition" in business networks - to cooperate and compete simultaneously, Industrial Marketing Management, God. 29, Br. 5, str. 411-426

3. Carayannis, E. G. i Campbell, D.F.J. (2009.) 'Mode 3' and 'Quadruple Helix': toward a 21st century fractal innovation ecosystem, International Journal of Technology Management, God. 46, Br. 3/4, str. 201-234.

4. Carayannis, E. G.; Barth, T.D. i Campbell, D.F.J. (2012.) The Quintuple Helix innovation model: global warming as a challenge and driver for innovation, Journal of Innovation and Entrepreneurship, God. 1, No. 1, doi:10.1186/2192-5372-1-2.

5. Darrisaw, A. (2017.) Millennials Want to Chase Their Passions But Can't Communicate What They Are, dostupno na: (1) Millennials Want to Chase Their Passions But Can't Communicate What They Are | Linkedln (pristup: 30.12.2020). 
6. Davidow, W. H. I Malone, M. S. (1992.) The Virtual Corporation, Harper Collins, New York, NY

7. Ebrahimi, M., Saives, A. L. i Holford, W.D. (2008.) Qualified ageing workers in the knowledge management process of high-tech businesses, Journal of Knowledge Management, God. 2, Br. 12, pp. 124-140

8. Ermine, J. L. (2010.) Knowledge crash and knowledge management, International journal of knowledge and systems science, God. 1, Br. 4, str. 79-95

9. Gentilviso, C. i Aikat, D. (2019.) Embracing the Visual, Verbal, and Viral Media: How PostMillennial Consumption Habits are Reshaping the News, U: Schulz, J.; Robinson, L.; Khilnani, A.; Baldwin, J.; Pait, H.; Williams, A.A.; Davis, J. i Ignatow, G. (ur.) Mediated Millennials (Studies in Media and Communications, Vol. 19), Emerald Publishing Limited, pp. 147-171

10. Gnyawali, D. R., He, J. i Madhavan, R. (2008.) Co-Opetition: Promises and challenges, U: Wankel, C. (ur.), 21st century management: A reference handbook, Thousand Oaks, Sage Publications, CA, str. 386-398

11. Ignatius, A. (2016), What CEOs Really Worry About, dostupno na: https://hbr.org/2016/11/ the-best-performing-ceos-in-the-world, (pristup 29.12.2020.)

12. Janand, A. i Notais, A. (2018.) Learning on the Move A Reassessment of Mobility through the Lens of Bateson's Learning Theory, The Learning Organization, God. 25, Br. 1, str. 113122

13. Kapp, K. M. (2012.) The Gamification of Learning and Instruction: Game-based Methods for Training and Tducation, Pfeiffer, San Francisco, CA

14. Lanier, K. (2017.) 5 things HR professionals need to know about Generation Z: Thought leaders share their views on the HR profession and its direction for the future, Strategic HR Review, God. 16, Br. 6, str. 288-290

15. Luo, Y. (2007.) A coopetition perspective of global competition, Journal of World Business, God. 42, str. 129-144

16. Meehan, M. (2016.) The next generation: what matters to gen we, dostupno na: The Next Generation: What Matters To Gen We (forbes.com) (pristup 29.12.2020.)

17. Rupčić, N. (2018.) Suvremeni menadžment - teorija i praksa, Ekonomski fakultet Sveučilišta u Rijeci, Rijeka

18. Šafránková, J. M. i Šikýřr, M. (2017.) Work expectations and potential employability of millennials and post-millennials on the Czech labor market, Oeconomia Copernicana, God. 8, Br. 4, str. 585-599

19. Schawbel, D. (2014.) Gen Y and Gen Z global workplace expectations study, dostupno na: Gen Y and Gen Z Global Workplace Expectations Study | Workplace Intelligence (pristup 29.12.2020)

20. Segran, E. (2016.) Your guide to generation Z: the frugal, brand-wary, determined antimillennials, dostupno na: Your Guide To Generation Z: The Frugal, Brand-Wary, Determined Anti-Mi (fastcompany.com), (pristup 29.12.2020)

21. Urick, M. i Sprinkle, T. (2018.) Three Generational Issues in Organizational Learning: Knowledge Management, Perspectives on Training, and "Low-stakes" Development, The Learning Organization, God. 25, Br. 1, str. 102-112 
22. Walters, D., Halliday, M. i Glaser, S. (2002.) Creating value in the "new economy“, Management Decision, God. 40, Br. 8, str. 775-781

23. Warhurst, R. P. i Black, K. E. (2015.) It's never too late to learn, Journal of Workplace Learning, God. 27, Br. 6, str. 457-472

24. Williams, A. (2015.) Move over, millennials, here comes generation Z, dostupno na: Move Over, Millennials, Here Comes Generation Z - The New York Times (nytimes.com) (pristup: 29.12.2020)

25. ... (2014): Hrvati ipak imaju pozitivan stav o poduzetništvu? Dostupno na: Hrvati ipak imaju pozitivan stav o poduzetništvu? (lider.media), (pristup 30.12.2020.)

Summary

\title{
CHARACTERISTICS OF POST-MILLENIALS OR THE GENERATION Z AS NEW PARTICIPANTS IN THE LABOR MARKET
}

\begin{abstract}
Along with social and technological development, human characteristics tend to change. Each generation, by means of mutual and intensive communication, creates new behavioral patterns and perspectives about the world and its development. Recently, a new generational cohort called postmillennials or the generation Z could be identified comprised of people born from 1996 onward. The question is raised how this new generation could fit with the demands of modern business and how they should be managed to ensure that they further contribute to the increase of productivity, efficiency, effectiveness and sustainability. Members of the generation $Z$ are primarily determined by their mergence with the information and communication technology and consumption of enormous amount of the information content, contributing to many adverse effects such as shortening of their attention span. The goal of this paper is therefore to determine characteristics of the generation $Z$ with the purpose to identify guidelines regarding managing this new human capital in the labor market with the emphasis on their effective learning, innovation but also reaching the goal of self-actualization.
\end{abstract}

Keywords: generation Z, post-millennials, human resource management, learning. 